\title{
VII. Remarks on the geological principles of Werner, and those of Mr. Smith
}

\section{Thomas Tredgold Esq.}

To cite this article: Thomas Tredgold Esq. (1818) VII. Remarks on the geological principles of Werner, and those of Mr. Smith , Philosophical Magazine Series 1, 51:237, 36-38, DOI: $10.1080 / 14786441808637500$

To link to this article: http://dx.doi.org/10.1080/14786441808637500

里 Published online: 27 Jul 2009.

Submit your article to this journal

Џ Article views: 2

Q View related articles $\asymp$ 
ring my voyage, and during my stay at the Cape, and the Isle of France, and my residence at this place.

Colombo, Nov. 3, 1816.

I remain, \&c.

John Davy.

VII. Remarks on the Geological Principles of Werner, and those of Mr. Smith. By Thomas Tredgold, Esg.

To Mr. Tilloch.

SrR, $-I_{N}$ the last number of the Edinburgh Review it is stated, that " it has been proved (and Werner was the first to make the observation) that the masses or strata that constitute the surface of the globe, present themselves in groups or assemblages, the members of which are generally associated, whenever they occur, and are so connected as to exhibit a certain unity of character.

"To such assemblages Werner gave the name of formations; and his doctrine (or hypothesis, if this latter term be preferred) is, that the exterior of the earth consists of a series of these formations, laid over each other, in a certain determinate order. Not that the whole series is anywhere complete; but that the relative place of its several members is never departed from. Thus, in a series A, B, C, D, it may happen that B or C, or both, may be occasionally wanting, and consequently $\mathrm{D}$ be found immediately above A; but the succession is never violated, nor the order inverted, by the discovery of $A$ above the formations $B$ or C, or D, nor of B above those that follow it, \&c."

"The only rival claimant to this doctrine, that we know of, is Mr. William Smith, the publisher of the Geological Map of England that has recently made its appearance-a work which it would be unjust to mention without adding, that it is of great and original value $\dot{r}$ indeed, regarding it as the production of an unassisted individual, of most extraordinary merit. For although the publication of this map was delayed till the year 1815, we have no doubt that Mr. Smith's acute and laborious researches originated entirely from the facts which came before him in examining the stratification of England many years ago; and that he was then, and long afterwards, wholly unacquainted with what had previously been done by Werner. The opinions of Mr. Smith, however, so nearly coincide with the doctrine of formations which we have just stated, that it would be difficult to express them in any other terms*."

From this quotation it appears, that this eloquent writer is

* Edinburgh Review, No. lvii. p. 71 . 
better acquainted with the results than with the principles on which Mr. Smith has proceeded in his researches; otherwise he certainly would not have considered them to be the same as those of Werner. It is true that the one supposes his formations are laid over one another in a determinate order, and the other has observed the same in the series of British strata; but the law of succession, of Werner, is purely hypothetical ; that of $\mathrm{Mr}$. Smith is the result of multiplied observations, and has been found to be correct as far as relates to the British strata.

Werner's law of succession, which he pretended was universal, evidently flowed from his hypothesis of the formation of the earth; an hypothesis which sets both reason and experience at defiance. The progress of inquiry would, however, have very soon shown its fallacy in the hands of any other person than Werner. But he saw that his law was not the law of Nature,-various strata were found to succeed one another in a different order from what he had assigned them in his hypothesis : this however was easily remedied by creating a distinction without a difference; and the formation was termed a newer, or an older formation, as the case required. Thus, we have neu granite and old granite, and the same of other substances:-besides, in the class of formations which Werner calls transition, there appears to be no regular order of succession whatever; for Dr. Thomson says, "they all alternate with each other, sometimes one sometimes another being undermost*." But even the classes of Werner do not always succeed one another in the order which Werner assigned them; granite being sometimes found above strata which contain petrifactions $\uparrow$.

Also, there is nothing more evident than that the Wernerians are without any fixt principles of tracing the structure of the earth; for they are always in doubt and difficulty-even in those places where they constantly reside, and where the tracing the strata presents no difficulty whatever $\ddagger$ : they write as mineralogists, but certainly not as geologists; - they say a formation occurs in this or that country, (seldom pointing out the place with the least precision, ) and that it is probably of the primitive, transition, or floetz class of formations-almost always as if the rock occurred in detached patches,-seldom describing it as a continued stratum; and, instead of attempting to show the structure of the country (on which this far-famed hypothesis is founded) by maps and sections, the Wernerians content themselves with giving a string of technical terms connected by expressions which are scarcely to be understood $\S$.

* System of Chemistry, iii. 558. ed. 1817. † Thomson's System of Chem. iii. 558 .

I Professor Jamieson's Elements of Geognosy iii. 205. § See the Description of the Hartz. Reg. Elem. Geog. iii. 71 
How differcnt is the course which Mr. Smith has pursued in his attempt to develop the structure of his native country ! His principles have arisen wholly out of his own observations on the strata of England; and I am not aware that he has attempted to found any general system of geology upon his discoveries. He has ascertained that certain shells are peculiar to certain strata*; and, with the help of this and some other principles equally original, he has succeeded in tracing the principal features of the structure of England; and by selecting a series of strata (many of them in other respects insignificant) he has been able to lay down on his Map the principal outlines of the geology of England and Wales.

If the results of Werner's researches had borne the least analogy to those of $\mathrm{Mr}$. Smith, we might have supposed them to have been conducted on similar principles; but it is too evident that the Wernerians search only for evidence to support a favourite hypothesis, while $\mathrm{Mr}$. Smith attempts to describe the real state of the earth's surface.

Jan. 14, 1818.

$$
\text { I am, sir, yours, \&c. \&c. }
$$

Thomas Tredgold.

VIII. On the Question "Whether Music is necessary to the Orator-to what Extent, and how most readily attainable?" By Henry Upington, Esq.

[Continued from Vol. L. p. 327.]

$$
\text { To Mr. Tilloch. }
$$

Blair's Hill, Cork, Dec. 17, 1817 .

I PERCEIve that my last letter, which treated of ancient music, was inserted in your Magazine for November; and in pursuance of my inquiry "Whether Music is necessary to the Orator,-to what Extent, and how most readily attainahle?" I have now to present you with some observations on our harmonical system. I cannot assure you that they are altogether new, for I am well aware that few ideas deserve the epithet "original ;" yet, such as they are, I shall submit them to your consideration.

Having taken it for the present as granted, that the Greeks were truly correct in acknowledging the fourth as the only perfeet concord + , my next inquiry was-Why that concord has been rejected by the moderns; while the subordinate fifth, and its inferior associates the thirds, have constituted (at the expense of

* See his “ Strata identified," \&c.

† The term "perfect concord" appertains to that note alone, which being struck in conjunction with any given fundamental and its upper octave shall constitute-not the most decided jingle, but the most intimate relation of both. 